\title{
Silicon nutrition mitigates salinity stress in maize by modulating ion accumulation, photosynthesis, and antioxidants
}

\author{
W.U.D. KHAN ${ }^{*+,}$, T. AZIZ**, M.A. MAQSOOD ${ }^{* *}$, M. FAROOQ ${ }^{* * *}$, Y. ABDULLAH ${ }^{*}$, \\ P.M.A. RAMZANI ${ }^{* * *}$, and H.M. BILAL ${ }^{* *}$ \\ Sustainable Development Study Centre, Government College University, Lahore-54000, Pakistan* \\ Institute of Soil and Environmental Sciences, University of Agriculture, Faisalabad-38040, Pakistan ${ }^{* *}$ \\ Department of Agronomy, University of Agriculture, Faisalabad, Pakistan ${ }^{* * *}$ \\ Cholistan Institute of Desert Studies, The Islamia University of Bahawalpur, Bahawalpur 63100, Pakistan ${ }^{* * * *}$
}

\begin{abstract}
Silicon is known to improve resistance against salinity stress in maize crop. This study was conducted to evaluate the influence of silicon application on growth and salt resistance in maize. Seeds of two maize genotypes (salt-sensitive 'EV 1089 ' and salt-tolerant 'Syngenta 8441') were grown in pots containing 0 and $2 \mathrm{mM}$ Si with and without $50 \mathrm{mM} \mathrm{NaCl}$. After detailed investigation of ion concentrations in different maize organs, both genotypes were further selected in hydroponic experiment on basis of their contrasting response to salinity stress. In the second experiment, pre-germinated seedlings were transplanted into nutrient solution with 0 and $60 \mathrm{mM} \mathrm{NaCl}$ with and without $2 \mathrm{mM}$ Si. Both genotypes differed significantly in their response to salinity. Silicon addition alleviated both osmotic and oxidative stress in maize crop by improving the performance of defensive machinery under salinity stress. Silicon application also improved the water-use efficiency in both tested genotypes under both normal and salinity stress conditions. In conclusion, this study implies that the silicon-treated maize plants had better chance to survive under salinity conditions and their photosynthetic and biochemical apparatus was working far better than that of silicon-non-treated plants.
\end{abstract}

Additional key words: chlorophyll; photosynthetic rate; total phenolics.

\section{Introduction}

Soil salinity generally prevails in arid to semiarid regions around the globe and is among the main causes for reduction of food production. Soil salinity causes physiological drought and ionic toxicity to plants (AcostaMotos et al. 2015) hampering growth and yield of plants (Tahir et al. 2011). A number of metabolic and physiological adaptations/mechanisms have been reported in plants to cope with salinity stress (Ashraf et al. 2010, Tahir et al. 2012). All of these mechanisms are directed (1) to maintain cell homeostasis by decreasing toxic ions $\left(\mathrm{Na}^{+}\right.$ and $\mathrm{Cl}^{-}$) accumulation or by increasing uptake of combating ions such as $\mathrm{K}^{+}$and $\mathrm{Ca}^{2+}$, (2) to decrease a growth rate, and (3) to scavenge the free radicals produced within plant cells by increasing antioxidant enzyme activities or content of phenolic compounds (Ashraf et al. 2010).
Plant species and even cultivars within species differ in one or more mechanisms; hence, they differ in their response to soil salinity. Many crops, which are reported as salt sensitive at early growth stage, proved to be salt tolerant at the later growth stage (Bhutta and Hanif 2010, Khan et al. 2015). At the early growth stage, tissues are less developed relative to a mature stage, so plants have no proper mechanisms to exclude toxic ions. This variation in response of plants to applied salinity at different growth stages have been reported in maize (Khan et al. 2015), but mechanisms underlying these variations are not studied in detail.

Several researchers have indicated beneficial effects of Si on plants under biotic and abiotic stresses (Tahir et al. 2012, Mateos-Naranjo et al. 2013, Khan et al. 2015, 2016a,b). Silicon application is helpful to combat many

Received 7 March 2017, accepted 28 July 2017, published as online-first 13 April 2018.

${ }^{+}$Corresponding author; e-mail: dr.waqasuddin@gcu.edu.pk

Abbreviations: APX - ascorbate peroxidase; BSA - bovine serum albumin; Chl - chlorophyll; CAT - catalase; $E$ - transpiration rate; $g_{\mathrm{s}}$ - stomatal conductance; NBT - nitroblue tetrazolium; $P_{\mathrm{N}}-$ photosynthetic rate; SOD - superoxide dismutase; WUE - water-use efficiency.

Acknowledgement: The authors highly acknowledge the Higher Education Commission (HEC) of Pakistan for financial assistance under NRPU project NO. 1439 awarded to Tariq Aziz and for HEC Indigenous Fellowship to Waqas-ud-Din Khan (Pin\# 112-23918-2AV1-356). 
kinds of these stresses, i.e., metal toxicity, drought or salinity (Cooke and Leishman 2011). An increase in the availability of $\mathrm{Si}$ in a growth medium may reduce the salinity-induced changes in plants by altering soil and plant factors (Gattullo et al. 2016), but specific mechanisms are still under debate. Abbas et al. (2015) reported that $\mathrm{Si}$ increases a root activity for nutrient uptake, inhibits transpiration, while reducing the osmotic stress. It also increases the activity of ATPase and PPase in plasma membrane which ultimately increases $\mathrm{K}^{+}$and decreases $\mathrm{Na}^{+}$uptake (Tuna et al. 2008). Chen et al. (2016) reported that $\mathrm{Si}$ application enhances $\mathrm{K}^{+}$concentration in sorghum by regulating its putrescine metabolism. Increased $\mathrm{K}^{+}$concentration by application of Si has already been reported by Tahir et al. (2012) in wheat under salinity stress.

Silicon application significantly increases the efficiency of photosynthetic apparatus of maize plant under salinity stress by enhancing the maximum quantum yield of primary photochemistry which maintains the conitinuity of electron transport chain (Khan et al. 2016 a). Abbas et al. (2015) confirmed that the photosynthetic rate $\left(P_{\mathrm{N}}\right)$, stomatal conductance $\left(g_{\mathrm{s}}\right)$, and water-use efficiency (WUE) significantly enhanced in okra crop by Si application under saline regimes.

Lipid peroxidation occurs under salinity stress which

\section{Materials and methods}

Experiment 1: The experiment was carried out in a wirehouse, Institute of Soil and Environmental Sciences (ISES), University of Agriculture Faisalabad, Pakistan $\left(31.4289^{\circ} \mathrm{N}, \quad 73.0750^{\circ} \mathrm{E}\right)$ under natural conditions (August-September, 2014). During this study, the wirehouse average temperature fluctuated from $32 \pm 5^{\circ} \mathrm{C}$ during the day and $20 \pm 5^{\circ} \mathrm{C}$ during the night. Relative humidity ranged from 45 (midday) to $85 \%$ (midnight) and light intensity varied from $400-1,300 \mu \mathrm{mol}$ (photon) $\mathrm{m}^{-2} \mathrm{~s}^{-1}$. The soil $(0-15 \mathrm{~cm})$ was collected from ISES research area. The collected soil was sieved through a $2.0-\mathrm{mm}$ sieve.

$\begin{array}{ll}\text { Soil texture } & \text { Clay loam } \\ \text { Sand } & 39 \% \\ \text { Silt } & 29 \% \\ \text { Clay } & 32 \% \\ \text { pH } & 7.91 \\ \text { Organic matter } & 0.7 \% \\ \mathrm{CaCO}_{3} & 21.9 \mathrm{~g} \mathrm{~kg}^{-1} \\ \mathrm{CEC} & 6.46 \mathrm{cmol}_{\mathrm{c} \mathrm{kg}}^{-1} \\ \mathrm{Fe} & 4.2 \mathrm{mg} \mathrm{kg}^{-1} \\ \mathrm{Zn} & 0.59 \mathrm{mg} \mathrm{kg}^{-1} \\ \mathrm{Na} & 98 \mathrm{mg} \mathrm{kg}^{-1} \\ \mathrm{~K} & 108 \mathrm{mg} \mathrm{kg}^{-1}\end{array}$

For physicochemical properties of soil, a subsample of the prepared soil was analyzed for texture (Gee and Bauder 1986), $\mathrm{pH}$, electrical conductivity (EC), cation exchange capacity (CEC), $\mathrm{CaCO}_{3}$ (Allison and Moodie 1965), organic matter (Nelson and Sommers 1982), and ion further induces oxidative damages. Si application mitigates such oxidative stress by increasing $\alpha$-tocopherol in barley (Liang et al. 2003). Silicon also stimulates leaf superoxide dismutase (SOD) activity and increased the activity of root $\mathrm{H}^{+}$-ATPase in the cell membrane of cucumber (Wang et al. 2015). Silicon induced improvement in plasma membrane integrity (Tahir et al. 2011); structure and functions may be attributed to the manipulation of peroxidation (stress-dependent process) of membrane lipids (Liang et al. 2003). Different scientists reported that exogenous $\mathrm{Si}$ application could increase the antioxidant enzyme activities by reducing the $\mathrm{H}_{2} \mathrm{O}_{2}$ concentrations in roots of salt-stressed sorghum crop (Liu et al. 2015) or due to reduction of lipid peroxidation in barley under salinity stress (Liang et al. 2003).

However, the information on the role of $\mathrm{Si}$ in alleviating the salinity-induced harmful effects on maize crop is not much explored and limited literature is available. In a preliminary germination experiments, we categorized maize genotypes according to their salinity tolerance (Khan et al. 2015). Two genotypes with contrasting salinity tolerance at germination were selected to identify possible salinity tolerance mechanisms induced by $\mathrm{Si}$ application. This study reported the variation in growth response of two contrasting maize genotypes.

contents. Seeds of maize genotypes Syngenta 8441 (salttolerant) and EV1089 (salt-sensitive) were sown ( $n=10$ in each) in each pot containing $10 \mathrm{~kg}$ of soil. Two concentrations of $\mathrm{Si}\left(0\right.$ and $\left.2 \mathrm{mM} \mathrm{H}_{2} \mathrm{SiO}_{3}\right)$ and salinity $(0$ and $50 \mathrm{mM} \mathrm{NaCl}$ ) were applied $7 \mathrm{~d}$ before seed sowing. Each treatment was replicated three times. Pots were randomized according to three-factor-factorial design. After $4 \mathrm{~d}$ of germination, four uniform plants were maintained in each pot. Distilled water was used to maintain soil moisture contents at field capacity in all pots during the experimental period. Plants were harvested after $25 \mathrm{~d}$ from sowing.

Plant samples were washed with distilled water and blotted dry with tissue paper. The plant samples were divided into roots and shoots, air-dried, and then oven dried at $65^{\circ} \mathrm{C}$ in a forced air driven oven (WFO-600ND, Tokyo Rikakiai Co. Ltd., Japan) to a constant mass. Dry matter yield of different plant parts (root, shoot, old and young leaf) was taken and plant samples were ground. Finely, ground plant samples $(0.1 \mathrm{~g})$ were digested in a diacid $\left(\mathrm{HNO}_{3}: \mathrm{HClO}_{4}\right)$ mixture (Jones and Case 1990). Plant samples were tested for the $\mathrm{Na}^{+}$and $\mathrm{K}^{+}$concentration in different plant parts by flame photometer (Jenway, PFP-7, UK).

Experiment 2: The hydroponic study was performed at the same wire-house during February-April, 2015. During the whole experimental period, environmental conditions remained: average day temperature of $28 \pm 3^{\circ} \mathrm{C}$, while 
$20 \pm 3^{\circ} \mathrm{C}$ at night, $45-80 \%$ relative humidity, and irradiance of $300-1,100 \mu \mathrm{mol}$ (photon) $\mathrm{m}^{-2} \mathrm{~s}^{-1}$.

Seeds of two selected (salt-sensitive 'EV 1089' and salt-tolerant 'Syngenta 8441') maize genotypes were sterilized in sodium hypochlorite solution $(0.1 \%)$ for $5 \mathrm{~min}$. Then, well washed river sand was taken in plastic trays and seeds were sown after rinsing with distilled water. After $10 \mathrm{~d}$, the uniform sized (with two expanded leaves) seedlings were transferred to small pots containing continuously aerated $128-\mathrm{L}$ nutrient solution, which contained macroelements $\left[2 \operatorname{mmol}\left(\mathrm{Ca}\left(\mathrm{NO}_{3}\right)_{2} \mathrm{~L}^{-1}, 0.2\right.\right.$ $\operatorname{mmol}\left(\mathrm{KH}_{2} \mathrm{PO}_{4}\right) \quad \mathrm{L}^{-1}, 4 \mathrm{mmol}\left(\mathrm{K}_{2} \mathrm{SO}_{4}\right) \mathrm{L}^{-1} ; 0.5 \mathrm{mmol}$ $\left.\left(\left(\mathrm{NH}_{4}\right)_{2} \mathrm{SO}_{4}\right) \mathrm{L}^{-1}, 1 \mathrm{mmol}\left(\mathrm{MgSO}_{4}\right) \mathrm{L}^{-1}\right]$ and microelements $\left[25 \mu \mathrm{mol}\left(\mathrm{H}_{3} \mathrm{BO}_{3}\right) \mathrm{L}^{-1}, 2 \mu \mathrm{mol}\left(\mathrm{MnSO}_{4}\right) \mathrm{L}^{-1}, 2 \mu \mathrm{mol}\right.$ $\left(\mathrm{ZnSO}_{4}\right) \mathrm{L}^{-1}, 0.5 \mu \mathrm{mol}\left(\left(\mathrm{NH}_{4}\right)_{2} \mathrm{MoO}_{7}\right) \mathrm{L}^{-1}, 1 \mu \mathrm{mol}\left(\mathrm{CuSO}_{4}\right)$ $\left.\mathrm{L}^{-1}, 0.1 \mathrm{mmol}(\mathrm{Fe}-\mathrm{EDTA}) \mathrm{L}^{-1}\right]$. There were two concentrations of $\mathrm{Si}\left(0\right.$ and $2 \mathrm{mM} \mathrm{H}_{2} \mathrm{SiO}_{3}$ ) and two levels of Salinity $(0$ and $60 \mathrm{mM} \mathrm{NaCl})$. Salinity stress was applied in two equal splits. The $\mathrm{Si}$ and $\mathrm{NaCl}$ treatments were applied after $5 \mathrm{~d}$ from the transplantation. Each treatment was replicated four times according to 3 -factor-factorial design.

The $\mathrm{pH}$ of the treatment solution was maintained at 6.5 using $0.01 \mathrm{~N} \mathrm{KOH}$ or $0.01 \mathrm{~N} \mathrm{HCl}$. The treatment solutions were well aerated and changed weekly. After $40 \mathrm{~d}$, four plants/replicates of each treatment were harvested and rinsed with distilled water and following biochemical parameters were measured.

Total phenolics in maize shoots and roots at vegetative growth stage: Total phenolics in the shoots and root extracts were determined colorimetrically following the method described by Singleton et al. (1999). Absorbance of the sample reaction mixture and gallic acid standards was measured at $760 \mathrm{~nm}$ on spectrophotometr (UV-1201, Shimadzu, Maryland, USA). The concentration of the total phenolics was expressed in $\mu \mathrm{g} \mathrm{g}^{-1}(\mathrm{FM})$.

Total soluble proteins at vegetative growth stage: Protein contents in green leaves of stressed and nonstressed plants was determined following Bradford (1976) method. Concentration of protein $\left[\mathrm{mg} \mathrm{g}^{-1}(\mathrm{FM})\right]$ was calculated by standard curve using different concentrations of bovine serum albumin (BSA).

Antioxidant enzyme assays at vegetative growth stage: Fresh leaf tissue was collected from each experimental unit. Leaf tissue $(200 \mathrm{mg})$ was ground to a fine powder using a precooled mortar and pestle, and then thoroughly homogenized in $1.2 \mathrm{~mL}$ of $0.2 \mathrm{M}$ potassium phosphate buffer (pH 7.8 with $0.1 \mathrm{mM}$ EDTA). The samples were centrifuged at $15,000 \times g$ for $20 \mathrm{~min}$ at $4^{\circ} \mathrm{C}$. The super- natant was removed, the pellet was resuspended in $0.8 \mathrm{~mL}$ of the same buffer, and the suspension was centrifuged for another $15 \mathrm{~min}$ at $15,000 \times \mathrm{g}$. The combined supernatants were stored on ice and used to determine antioxidant enzyme activities. spectrophotometr (UV-1201, Shimadzu, Maryland, USA).

Total superoxide dismutase (SOD, EC: 1.15.1.1) activity in leaves was assayed using a modified nitroblue tetrazolium (NBT) method (Bayer and Fridovich 1987). The enzyme activity [unit $\mathrm{mg}^{-1}$ (protein)] of a sample was determined from a standard curve obtained by using pure SOD. Ascorbate peroxidase (APX, EC: 1.11.1.11) activity was assayed using a modified method of Nakano and Asada (1981). APX activity was determined from the decrease in absorbance at $290 \mathrm{~nm}$ due to oxidation of ascorbate in the reaction. The extinction coefficient of $2.8 \mathrm{mM}^{-1} \mathrm{~cm}^{-1}$ for reduced ascorbate was used in calculating the enzyme activity that was expressed in terms of $\mathrm{mM}$ (ascorbate) $\mathrm{min}^{-1} \mathrm{mg}^{-1}$ (protein).

Catalase (CAT) activity was measured by decrease in absorbance at $240 \mathrm{~nm}$ due to $\mathrm{H}_{2} \mathrm{O}_{2}$ extinction. The activity was calculated in terms of $\mathrm{mM}\left(\mathrm{H}_{2} \mathrm{O}_{2}\right) \mathrm{min}^{-1} \mathrm{mg}^{-1}$ (protein) at $25 \pm 2{ }^{\circ} \mathrm{C}$ (Cakmak and Marschner 1992).

Gas-exchange parameters: Carbon dioxide assimilation rate $\left(P_{\mathrm{N}}\right)$, transpiration rate $(E)$, and stomatal conductance $\left(g_{\mathrm{s}}\right)$ were recorded in the morning during 8:00-9:00 $\mathrm{h}$ from the fully expanded penultimate leaves (one per plant and three extra taken randomly) using an infrared gas analyzer CIRAS (Model-3, Amesbury, Massachusetts, USA) in an open system $30 \mathrm{~d}$ after transplantation at ambient $\mathrm{CO}_{2}$ concentration of $390 \mathrm{ppm}$, temperature of $26^{\circ} \mathrm{C}, 55 \pm 5 \%$ relative humidity, and a photon flux density of $1,002 \mu \mathrm{mol}$ $\mathrm{m}^{-2} \mathrm{~s}^{-1}$. Water-use efficiency (WUE) was estimated as a ratio of $P_{\mathrm{N}}$ to $E$ (Ahmad et al. 2013)

Chlorophyll (Chl) concentration was determined in fully expanded leaf harvested $40 \mathrm{~d}$ after transplantation. Leaf sample ( $1 \mathrm{~g}$ ) was ground in $90 \%$ acetone using a pestle and mortar. The absorbance was measured with a UV/visible spectrophotometer (Shimadzu, UV-1201, Kyoto, Japan) and $\mathrm{Chl}$ concentrations were calculated using the equation proposed by Strain and Svec (1966).

The remaining plants from each pot grounded and dry mass was recorded.

Statistical analysis: Data was statistically analyzed by Microsoft Excel $2010^{\circledR}$ (Microsoft Cooperation, USA) and Statistix $8.1^{\mathbb{B}}$ (Analytical Software, Tallahassee, USA). Significantly different treatment means were separated using least significant difference (LSD) test (Steel et al. 1997). 


\section{Results}

\section{Study 1}

Biomass production: We found significant main and interactive effects of genotypes, salinity, and silicon application on plant biomass production (Table 1). Salinity stress significantly decreased plant shoot and root dry matter in both genotypes, however, the decrease in shoot dry matter was higher in the EV-1089 (52\%) genotype than that in Syngenta 8441 (45\%). Silicon application caused a significant increase in shoot and root dry matter of both genotypes under normal as well as saline conditions and this increase was higher in EV 1089. Shoot to root ratio was different in both genotypes as the root growth was higher in EV 1089 compared to Syngenta 8441 at all treatments.

Ion concentrations: There were significant main and interactive effect of genotypes, salinity, and silicon on shoot $\mathrm{Na}^{+}$and $\mathrm{K}^{+}$concentration in various plant organs (Table 1). Salinity stress significantly increased the $\mathrm{Na}^{+}$ concentration in all plant organs; nonetheless, variations Moreover, both genotypes varied significantly in $\mathrm{Na}^{+}$ accumulation in different organs. Maximum increase in $\mathrm{Na}^{+}$concentration was noted in EV-1089 in roots, young and old leaves. In case of Syngenta 8441, the increase in $\mathrm{Na}^{+}$concentration was observed in all organs except for young leaves (Table 1).

Silicon application had variable effect on $\mathrm{Na}^{+}$concentration in different plant organs. It caused a decrease in $\mathrm{Na}^{+}$ concentration in young leaves and stems in both genotypes, while an increase was observed in roots and old leaves (Table 1). Application of Si under salinity stress significantly decreased $\mathrm{Na}^{+}$concentration compared to saline treatment in both genotypes and maximum decrease was observed in case of EV-1089 in roots (50\%), young (45\%) and old leaves $(32 \%)$. The decrease in $\mathrm{Na}^{+}$concentration was not prominent in all plant organs in Syngenta 8441, when Si was applied.

Contrary to $\mathrm{Na}^{+}$concentration, salinity stress reduced genotypes; however, the reduction was variable among organs and genotypes (Table 1). Maximum reduction in $\mathrm{K}^{+}$ concentration was observed in leaves of EV 1089 compared to their respective controls. Surprisingly, salinity stress did not affect the root $\mathrm{K}^{+}$concentration in both genotypes. In case of a stem, a higher decline in $\mathrm{K}^{+}$concentration was observed in EV-1089 compared to Syngenta 8441. Nonetheless, the application of Si significantly improved the leaf $\mathrm{K}^{+}$concentration in leaves and prominent increase was observed in Syngenta 8441. Silicon application under salinity stress also improved the $\mathrm{K}^{+}$concentration in all plant organs in both genotypes except roots. The two fold increase in $\mathrm{K}^{+}$concentration was observed in younger leaves of EV 1089 with Si application under salinity stress compare to the saline treatment only. were observed in different organs for $\mathrm{Na}^{+}$concentration. $\mathrm{K}^{+}$concentration in all plant organs in both maize

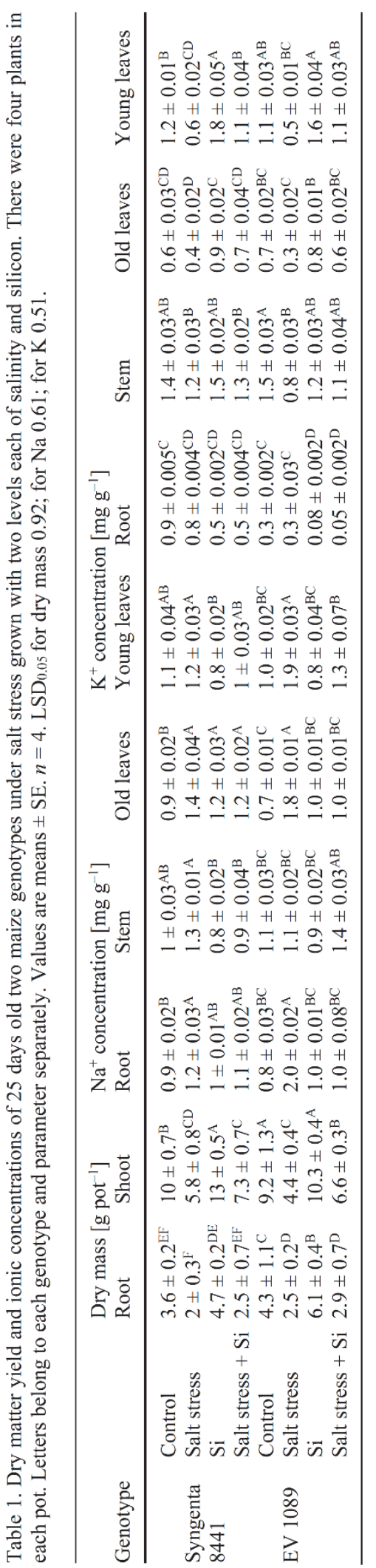


Study 2

Plant biomass: We observed significant main and interactive effects of genotypes, salinity, and silicon on plant dry matter production (Fig. 1). Mean dry matter production of all organs was higher in Syngenta 8441 than that in EV 1089. Salinity stress significantly decreased dry matter production of all organs in both genotypes. Reduction in plant dry mass was higher in EV 1089 (44\%) than that in Syngenta (38\%). Comparing various plant organs, maximum reduction in dry matter was observed in young leaves of Syngenta 8441, while it was contrary to EV 1089, where a more apparent reduction was observed in old leaves. Application of Si improved dry matter of treated plants relative to control (Fig. 1) in both genotypes except for young leaves of Syngenta 8441 .

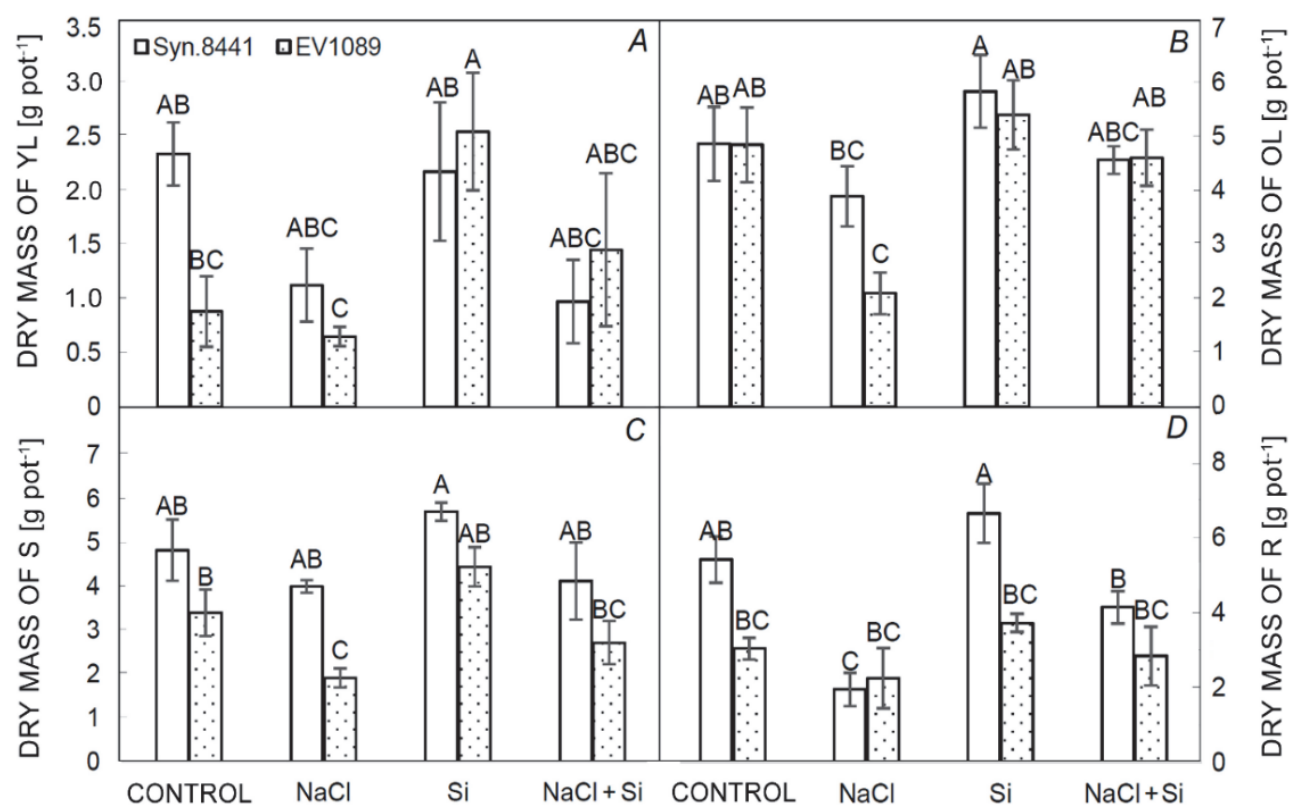

Fig. 1. Dry mass of 40-day-old maize genotypes ( $A$ : young leaves, $B$ : old leaves, $C$ : stem, and $D$ : roots) influenced by the $S i$ application under salt stress developed after plants were established in nutrient solution. Bars sharing similar letters are statistically similar to each other at $p \leq 0.05$. Letters belong to each part of both maize genotypes separately and values are means $\pm \mathrm{SE}$. $n=4$. OL - old leaf; YL young leaf; $\mathrm{S}$ - shoot; $\mathrm{R}$ - root; Syn.8441 = Syngenta 8441. $\mathrm{LSD}_{0.05}$ : interaction effect for $\mathrm{OL}=2.0 ; \mathrm{YL}=1.5 ; \mathrm{S}=1.9 ; \mathrm{R}=1.9$ ).

Total soluble phenolics: Genotypes differed significantly in their response to applied salinity and $\mathrm{Si}$ application in terms of root and shoot total phenolics (Fig. $2 A, B$ ). Salinity stress decreased the shoot total phenolics in Syngenta 8441 only, while there was no effect on root total phenolics in both genotypes. Silicon application also improved the shoot total phenolics in Syngenta 8441 under normal conditions, while there was no effect observed in saline environment.

Antioxidant enzymes activity: There was no effect of salinity stress on shoot SOD activity in both genotypes (Fig. $3 A$ ). SOD activity increased with $\mathrm{Si}$ application in $\mathrm{EV}$ 1089, while the effect was insignificant in case of Syngenta 8441 .

APX activity in maize leaves differed significantly in both genotypes. The APX activity decreased (32\%) significantly in EV-1089 because of applied salinity (Fig. $3 B$ ), while the effect was insignificant in case of Syngenta 8441. Silicon application significantly improved APX activity in both maize genotypes grown with and without salinity stress; however, maximum increase (35\%) was observed in EV 1089 with Si application under salinity stress relative to saline treatment only.

Genotypes did not differ in CAT activities at all treatments except that with $\mathrm{Si}$ application (Fig. 3C). Salinity stress significantly decreased the CAT activity in Syngenta 8441. Interestingly, application of Si deceased CAT activity relative to control in EV 1089 under normal conditions, while it improved CAT activity after the saline treatment in the same genotype.

Total soluble protein contents: There were significant main and interactive effects of salinity, genotype, and $\mathrm{Si}$ application on total soluble protein contents in maize leaves (Fig. 4). Genotypes did not differ significantly in their total soluble proteins, when grown without salinity stress; however, differences between both genotypes were significant, when $\mathrm{NaCl}$ was applied in nutrient solution. Salinity stress significantly declined total protein contents and reduction was prominent in EV 1089. Silicon application caused a significant increase $(>50 \%)$ of protein contents in case of EV 1089 under both normal and saline treatments. 


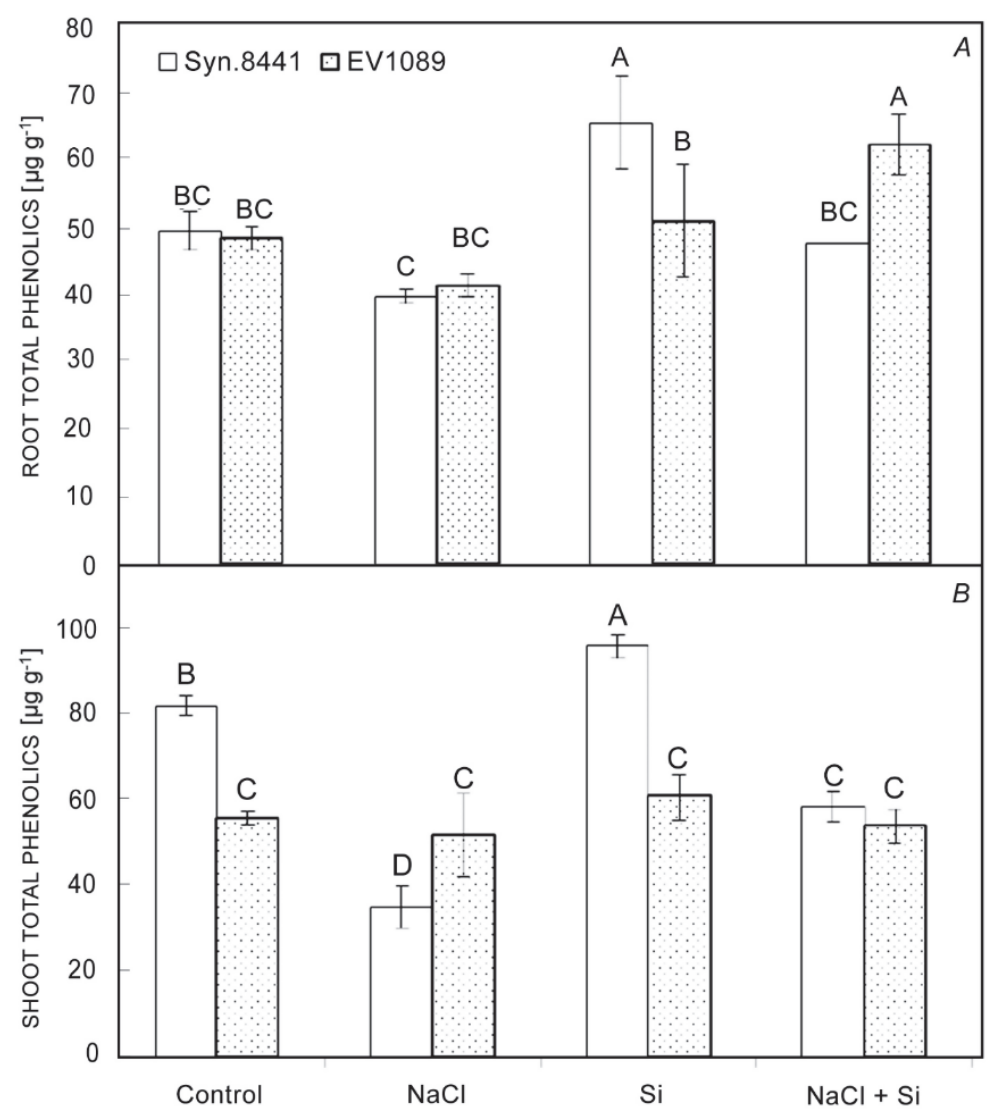

Fig. 2. Influence of silicon application on $(A)$ root and $(B)$ shoot total phenolic contents in two maize genotypes salt stress. Bars sharing similar letters do not differ from each other at $p \leq 0.05$. Values are means \pm SE. $n=4$. Syn.8441 - Syngenta 8441 . $\mathrm{LSD}_{0.05}$ : interaction effect for root total phenolics $=$ 10.0; for shoot total phenolics $=11.2$ ).
Gas-exchange parameters: $P_{\mathrm{N}}$ was significantly influenced by the interactive effect of salinity, $\mathrm{Si}$, and genotypes (Table 2). There was no difference between the genotypes for $P_{\mathrm{N}}$ under normal conditions. Salinity stress significantly decreased $P_{\mathrm{N}}$ in both genotypes; however, reduction was more prominent in Syngenta 8441. Silicon addition decreased the reduction in $P_{\mathrm{N}}$ among both genotypes compared to salinity treatment. The reduction of $P_{\mathrm{N}}$ in EV 1089 decreased from 41 to $33 \%$ in the treatment where plants were grown with Si under salinity stress.

The absolute value of $E$ was higher in Syngenta 8441 relative to EV 1089 under control conditions (Table 2). Salinity stress significantly decreased $E$ in Syngenta 8441, but no significant difference was found in EV 1089 under applied stress. Silicon application had no significant influence on $E$ in both genotypes where plants were grown with Si under salinity stress.

Stomatal conductance $\left(g_{\mathrm{s}}\right)$ of maize genotypes was significantly influenced by the interactive effect of salinity, Si, and genotype (Table 2). The absolute value of $g_{\text {s }}$ was higher in Syngenta 8441 relative to EV 1089 under control conditions. Salinity stress significantly decreased $g_{\mathrm{s}}$ in both genotypes, however, the reduction was variable in both genotypes. Silicon addition improved $g_{\mathrm{s}}$ in plants grown with salinity. The reduction of $g_{\mathrm{s}}$ in Syngenta 8441 decreased from 45 to $23 \%$ in the treatment, where plants were grown with Si under salinity stress.

Salinity stress significantly decreased the WUE of both genotypes (Table 2); however, maximum reduction in WUE was observed in Syngenta 8441 (65\%), while EV1089 showed minimum reduction $(9 \%)$ relative to control. Silicon addition significantly improved WUE compared to the saline treatment only. The reduction of WUE in Syngenta 8441 decreased from 65 to $3 \%$ by $\mathrm{Si}$ treatment under salinity stress.

Chl: Salinity stress significantly reduced the Chl contents $(\mathrm{Chl} a$ and $\mathrm{Chl} b$ ) in both genotypes. Salinity stress caused a significant decrease (60\%) in Chl $a$ in EV1089 (Table 2); however, Syngenta 8441 showed minimum reduction (40\%) compared with control. Silicon application increased the $\mathrm{Chl} a$ concentration relative to saline treatment only. Chl a concentration in the genotype EV1089 decreased from 60 to $31 \%$ by the Si treatment under salinity stress compared to salinity treatment only.

Similarly, salinity stress significantly decreased $\mathrm{Chl} b$ concentration in both genotypes (Table 2); however, reduction was variable in both genotypes. Chl $b$ concentration in Syngenta 8441 increased 6-folds if grown with Si under salinity stress relative to saline treatment only. 


\section{Discussion}

Effect of salinity stress on plant biomass: Soil salinity caused severe reduction in root and shoot biomass production in crops at early growth stages (Kafi and Rahimi 2011). In wheat and barley, the germination period is known to be more sensitive to salinity stress compared to later growth stages (Bhutta and Hanif 2010, Khayatnezhad et al. 2010). Maize genotypes were selected from a screening experiment against salinity stress at germination and the genotype EV 1089 was selected as the sensitive one, while the genotype Syngenta 8441 was found as salt tolerant by different germination parameters (Khan et al. 2015). In two different experiments, both of these genotypes were selected to study their response at later growth stages (vegetative). As expected, salinity stress decreased significantly shoot and root biomass of both genotypes in this experiment. Interestingly, no significant effect of salinity was observed on dry matter yield in both genotypes when crops were grown in hydroponics (Fig. 1). The effect was more pronounced in pots as germination was more affected by salinity stress. This might be due to the presence of salinity in pots during the germination of both genotypes which leads to the reduction in growth of genotype EV 1089, while in hydroponics, salinity stress was applied when plants were 18-d old. Therefore, the plants survived in saline environments and showed significant growth before the application of salinity stress (Table 3). Khatoon et al. (2010) also reported that maize is sensitive to salinity stress at early growth stages but tolerant at later stages. Crops vary in salinity-stress tolerance due to their genetic variability and might be sensitive at early growth stages due to poor development of defensive mechanisms (Morales et al. 2012). However, if salinity stress is applied in later stages, plants may develop mechanisms to withstand it (Munns and Tester 2008).

Ion concentration in different plant organs: Salinity stress alters the nutritional balance by increasing $\mathrm{Na}^{+}$ concentration and decreasing $\mathrm{K}^{+}$in both root and shoot of maize genotypes (Table 1). As expected, salt-sensitive EV 1089 exhibited higher $\mathrm{Na}^{+}$concentration in roots, young and old leaves relative to Syngenta 8441 (Table 1). Lower concentration of $\mathrm{Na}^{+}$in roots and leaves of Syngenta 8441 indicated some possible mechanisms for $\mathrm{Na}^{+}$exclusion (Munns and Tester 2008). Furthermore, Syngenta 8441 accumulated more $\mathrm{Na}^{+}$in old leaves than in young leaves, due to salinity tolerance mechanism preventing $\mathrm{Na}^{+}$to be accumulated in metabolically actives plant parts, i.e., young leaves and roots. Increased $\mathrm{Na}^{+}$concentration in plant shoots caused a significant decrease in $\mathrm{K}^{+}$uptake (Liu et al. 2015). Decrease in $\mathrm{K}^{+}$concentration in plant tissues grown under salinity stress is well reported phenomenon in different plant species (Tahir et al. 2012). It causes significant reduction in plant growth as $\mathrm{K}^{+}$is involved in a number of defense mechanisms against abiotic stresses (Wang et al. 2015).

Effect of silicon application on plant growth and physiology under salinity stress: Silicon application improved growth of both genotypes at normal as well as saline conditions in both experiments (Table 1, Fig. 1). Silicon is known to increase salinity tolerance in plants (Liang et al. 2005, Tahir et al. 2011, Khan et al. 2016b). Possible mechanisms of increased salinity tolerance may vary within species and even within genotypes of the same species. Silicon works as a plant $\mathrm{Na}^{+}$detoxification by increasing cell-wall $\mathrm{Na}^{+}$binding in wheat (Khan et al. 2016b) thereby decreasing its movement towards shoot/leaves. In this experiment, Si application decreased $\mathrm{Na}^{+}$concentration in both young and old leaves of saltsensitive genotype (EV 1089); however, $\mathrm{Na}^{+}$cell-wall binding at roots was not observed in both genotypes as indicated by decreased or the same $\mathrm{Na}^{+}$concentration in roots (Table 1). Thus, $\mathrm{Na}^{+}$exclusion at a leaf or shoot level is obvious in the salt-sensitive genotype upon $\mathrm{Si}$ application, increasing its growth at salinity stress. However, there was the insignificant difference in $\mathrm{Na}^{+}$ concentration in young and old leaves of Syngenta 8441 . This clearly indicated that effect of Si on salinity tolerance may differ between genotypes.

Potassium concentration in different plant tissues: High requirement for $\mathrm{K}^{+}$was reported for cell expansion, osmoregulation, stomatal opening, and carbon dioxide $\left(\mathrm{CO}_{2}\right)$ supply for photosynthesis (Khan et al. 2016a). Potassium concentration in different tissues is an important indicator of salinity tolerance and plant growth under salinity stress (Tahir et al. 2011, Khan et al. 2016b). Genotypes having ability to maintain higher $\mathrm{K}^{+}$concentration are considered being more tolerant to salinity stress. It has been reported that stem and leaves of cereal plants possess better mechanism to exclude $\mathrm{Na}^{+}$and maintained higher concentrations of $\mathrm{K}^{+}$(Morales et al. 2012). As shown in our experiment, the younger leaves of both genotypes maintained the high content of $\mathrm{K}^{+}$relative to older leaves (Table 1). Moreover, the difference was more prominent in Syngenta 8441 (salt tolerant). Silicon application caused a significant increase in $\mathrm{K}^{+}$concentration in shoots in both genotypes grown under salinity stress (Table 1). This high $\mathrm{K}^{+}$concentration can be attributed to increase of root plasma membrane H-ATPase pump due to Si application (Liu et al. 2015). Increased $\mathrm{K}^{+}$concentration in wheat shoots have been already reported because of $\mathrm{Si}$ application (Tahir et al. 2012). 


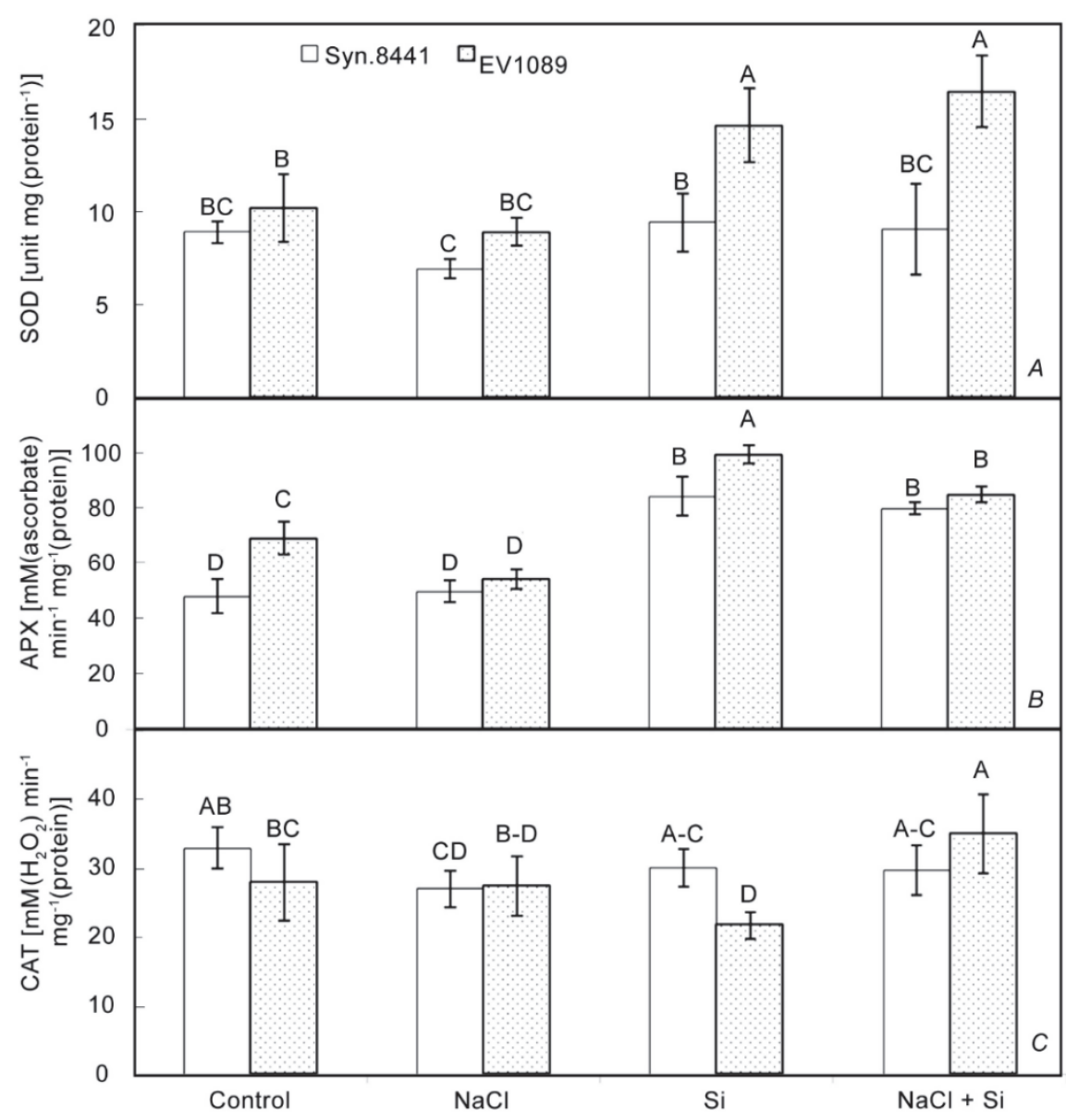

Fig. 3. Influence of silicon application on $(A)$ superoxide dismutase (SOD), $(B)$ ascorbate peroxidase (APX), and $(C)$ catalase (CAT) activities in two maize genotypes salt stress. Bars sharing similar letters are statistically similar to each other at $p \leq 0.05$. Values are means \pm SE. $n=4$. Syn. 8441 - Syngenta 8441. LSD $_{0.05}$ : interaction effect for $\mathrm{SOD}=2.34$; for APX $=6.84$; for CAT $=4.24$.

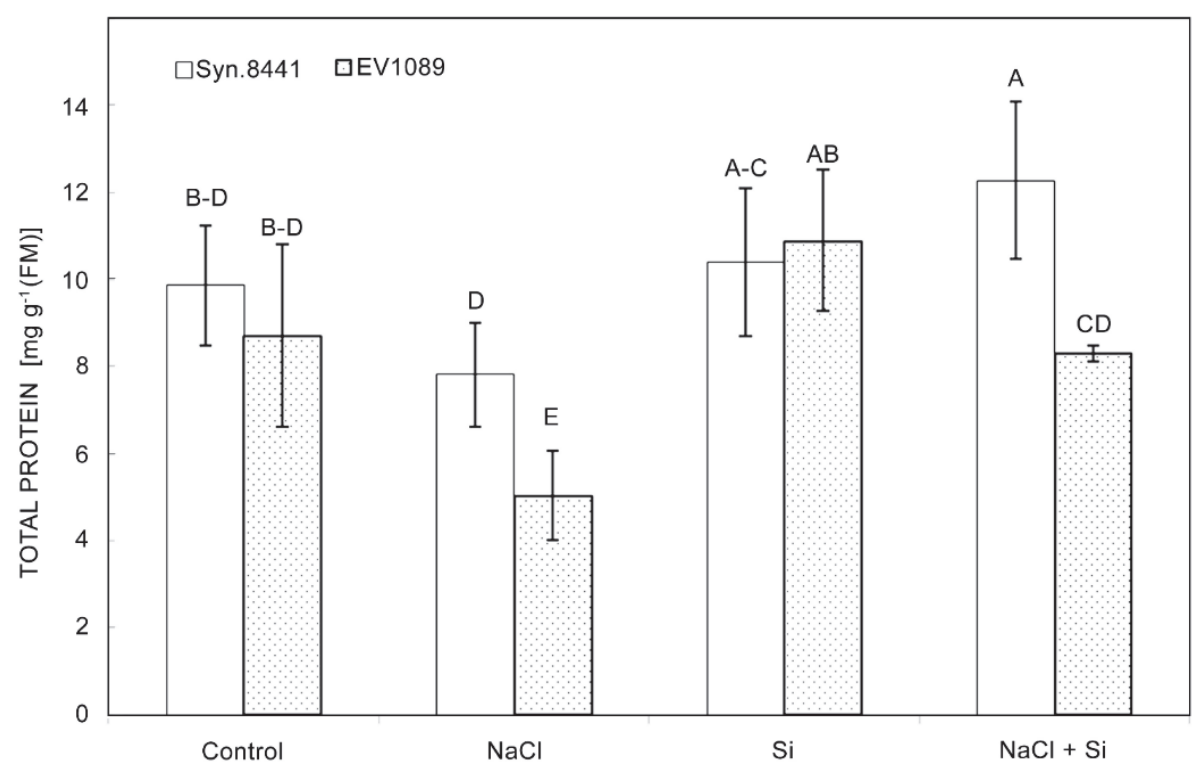

Fig. 4. Total soluble protein contents of 40-d-old maize genotypes influenced by the Si application under salt stress developed after plants were established in the nutrient solution in pots, where bars sharing similar letters are statistically similar to each other at $p \leq 0.05$. Values are means \pm SE. $n=4$. Syn. $8441-$ Syngenta 8441 . LSD 0.05 : interaction effect for total protein $=2.3$. 
Table 2. Influence of silicon application on gas exchange, chlorophyll (Chl) contents, and water-use efficiency (WUE) in two maize genotypes under salt stress. Values are means \pm SE. $n=4$. $P_{\mathrm{N}}-$ net photosynthetic rate; $E$ - transpiration rate; $g_{\mathrm{s}}-$ stomatal conductance. $\mathrm{LSD}_{0.05}: P_{\mathrm{N}}-4.5 ; E-4.07 ; g_{\mathrm{s}}-39.7$; WUE -0.98 ; Chl $a-0.19$; Chl $b-0.23$.

\begin{tabular}{llllll}
\hline Parameter & Genotype & Control & $\mathrm{NaCl}$ & $\mathrm{Si}$ & $\mathrm{NaCl}+\mathrm{Si}$ \\
\hline$P_{\mathrm{N}}\left[\mu \mathrm{mol} \mathrm{m}{ }^{-2} \mathrm{~s}^{-1}\right]$ & Syn.8441 & $10.8 \pm 0.8^{\mathrm{A}}$ & $3.4 \pm 0.5^{\mathrm{C}}$ & $8.2 \pm 0.3^{\mathrm{AB}}$ & $3.9 \pm 0.6^{\mathrm{C}}$ \\
& EV1089 & $11.9 \pm 0.4^{\mathrm{A}}$ & $6.6 \pm 0.6^{\mathrm{BC}}$ & $11.1 \pm 0.2^{\mathrm{A}}$ & $7.2 \pm 0.7^{\mathrm{BC}}$ \\
$E\left[\mathrm{mmol} \mathrm{m}^{-2} \mathrm{~s}^{-1}\right]$ & Syn.8441 & $5.5 \pm 0.3^{\mathrm{A}}$ & $3.7 \pm 0.3^{\mathrm{AB}}$ & $5.5 \pm 0.2^{\mathrm{A}}$ & $4.3 \pm 0.3^{\mathrm{AB}}$ \\
& EV1089 & $4.1 \pm 0.3^{\mathrm{AB}}$ & $4.1 \pm 0.4^{\mathrm{AB}}$ & $4.0 \pm 0.1^{\mathrm{AB}}$ & $3.0 \pm 0.1^{\mathrm{B}}$ \\
$g_{\mathrm{s}}\left[\mathrm{mmol} \mathrm{m}^{-2} \mathrm{~s}^{-1}\right]$ & Syn.8441 & $210 \pm 1.7^{\mathrm{A}}$ & $106 \pm 3.3^{\mathrm{C}}$ & $218 \pm 4.5^{\mathrm{A}}$ & $156 \pm 4.6^{\mathrm{B}}$ \\
& EV1089 & $131 \pm 1.5^{\mathrm{BC}}$ & $95 \pm 4.4^{\mathrm{C}}$ & $124 \pm 5.4^{\mathrm{BC}}$ & $113 \pm 2.4^{\mathrm{C}}$ \\
$\mathrm{WUE}$ & Syn.8441 & $3.9 \pm 0.6^{\mathrm{BC}}$ & $2.4 \pm 0.7^{\mathrm{D}}$ & $7.3 \pm 1.2^{\mathrm{A}}$ & $4.4 \pm 1.3^{\mathrm{B}}$ \\
& EV1089 & $3 \pm 1.6^{\mathrm{CD}}$ & $2.9 \pm 1^{\mathrm{CD}}$ & $6.7 \pm 1.8^{\mathrm{A}}$ & $3.3 \pm 0.8^{\mathrm{C}}$ \\
$\mathrm{Chl} a\left[\mu \mathrm{g} \mathrm{g}^{-1}(\mathrm{FM})\right]$ & Syn.8441 & $0.5 \pm 0.01^{\mathrm{BC}}$ & $0.3 \pm 0.02^{\mathrm{CD}}$ & $1.3 \pm 0.1^{\mathrm{A}}$ & $0.6 \pm 0.03^{\mathrm{B}}$ \\
& EV1089 & $0.5 \pm 0.01^{\mathrm{BC}}$ & $0.2 \pm 0.03^{\mathrm{D}}$ & $0.4 \pm 0.01^{\mathrm{C}}$ & $0.4 \pm 0.04^{\mathrm{C}}$ \\
$\mathrm{Chl} b\left[\mu \mathrm{gg} \mathrm{g}^{-1}(\mathrm{FM})\right]$ & Syn.8441 & $0.7 \pm 0.01^{\mathrm{A}}$ & $0.1 \pm 0.01^{\mathrm{B}}$ & $1.1 \pm 0.02^{\mathrm{B}}$ & $0.7 \pm 0.03^{\mathrm{A}}$ \\
& EV1089 & $0.6 \pm 0.04^{\mathrm{A}}$ & $0.2 \pm 0.02^{\mathrm{B}}$ & $0.6 \pm 0.01^{\mathrm{A}}$ & $0.7 \pm 0.01^{\mathrm{A}}$ \\
\hline
\end{tabular}

Table 3. Relationship (Pearson's coefficient correlation) among maize dry mass and its photosynthetic, antioxidant parameters with Si application under salt stress in hydroponic study. $n=45$. ns - insignificant; ${ }^{*}-$ significant at $p \leq 0.05 ;{ }^{* *}-$ significant at $p \leq 0.01 . P_{\mathrm{N}}-$ net photosynthetic rate; $E$ - transpiration rate; $g_{\mathrm{s}}$ - stomatal conductance; CAT - catalase; APX - ascorbate peroxidase; SOD - superoxide dismutase; DM - dry mass.

\begin{tabular}{|c|c|c|c|c|c|c|c|c|c|}
\hline Parameter & $P_{\mathrm{N}}$ & CAT & $E$ & APX & Protein & SOD & $\mathrm{DM}$ & $g_{\mathrm{s}}$ & Root phenol \\
\hline CAT & $-0.1220^{\mathrm{ns}}$ & & & & & & & & \\
\hline E & $0.3024^{\mathrm{ns}}$ & 0.1034 ns & & & & & & & \\
\hline APX & $0.2139^{\mathrm{ns}}$ & $-0.2271^{\mathrm{ns}}$ & $-0.1959^{\mathrm{ns}}$ & & & & & & \\
\hline Protein & $0.1079^{\mathrm{ns}}$ & $-0.0281^{\mathrm{ns}}$ & $0.3463^{\mathrm{ns}}$ & $0.5532^{\mathrm{ns}}$ & & & & & \\
\hline SOD & $0.3663^{\mathrm{ns}}$ & $0.0747^{\mathrm{ns}}$ & $-0.4949^{\mathrm{ns}}$ & $0.7273^{*}$ & $0.1287^{\mathrm{ns}}$ & & & & \\
\hline $\mathrm{DM}$ & $0.3776^{\mathrm{ns}}$ & $0.0814^{\mathrm{ns}}$ & $0.7130^{*}$ & $0.3878^{\mathrm{ns}}$ & $0.7564^{*}$ & $0.0551^{\mathrm{ns}}$ & & & \\
\hline$g_{\mathrm{s}}$ & $0.286^{\mathrm{ns}}$ & $0.362^{\mathrm{ns}}$ & $0.8974^{* *}$ & $0.033^{\mathrm{ns}}$ & $0.587^{\mathrm{ns}}$ & $-0.238^{\mathrm{ns}}$ & $0.877^{* *}$ & & \\
\hline Root phenol & $0.2619^{\mathrm{ns}}$ & $0.442^{\mathrm{ns}}$ & $0.1885^{\mathrm{ns}}$ & $0.6478^{*}$ & $0.3927^{\mathrm{ns}}$ & $0.5620^{\mathrm{ns}}$ & $0.6262^{*}$ & $0.5028^{\mathrm{ns}}$ & \\
\hline Shoot phenol & $0.4513^{\mathrm{ns}}$ & $0.280^{\mathrm{ns}}$ & $0.8472^{* *}$ & $0.226^{\mathrm{ns}}$ & $0.447^{\mathrm{ns}}$ & $-0.004^{\mathrm{ns}}$ & $0.8366^{* *}$ & $0.9136^{* *}$ & $0.6542^{*}$ \\
\hline
\end{tabular}

Total phenolics, enzyme activities and total proteins: A number of adaptive mechanisms have been reported in higher plants to reduce oxidative damage caused by salinity stress, through the biosynthesis of a cascade of antioxidants (Ashraf et al. 2010, Munns and Tester 2008). Among antioxidants, phenolic compounds, such as phenolic acids, flavonoids, and proantho-cyanidins, play an important role in scavenging free radicals (Waskiewicz et al. 2013). Salinity stress reduces root and shoot total phenolics (Ashraf et al. 2010); similar reduction in shoot total phenolics was observed in Syngenta 8441 (Fig. 2). Salinity stress did not affect total phenolics in shoot and root of EV 1089 genotype. Silicon application enhanced the total phenolic compounds in roots of both genotypes and shoots of Syngenta 8441 under stress conditions (Fig. 2) thereby increasing the tolerance against salinity by scavenging free radicals (Waskiewicz et al. 2013).

The overproduction of reactive oxygen species (ROS) in plants is toxic and cause damage to the subcellular components such as proteins, carbohydrates, lipids, and DNA which ultimately leads to the cell death (Abbas et al. 2015). Salinity stress has variable effects on different enzyme activities. APX activities were reduced in EV
1089, while CAT activity was reduced in Syngenta 8441 . Application of $\mathrm{Si}$ enhanced enzyme activities in both genotypes under salinity stress (Fig. 3). These enzymes (SOD, CAT, and APX) are very important as the first line of defense in order to scavenge ROS produced in the PSI during light reaction. SOD distribution varies in different plant organs, such as mitochondria, cytosol, and chloroplast, where it catalyzes the detoxification of superoxide free radicle and convert it into $\mathrm{H}_{2} \mathrm{O}_{2}$ (Abbas et al. 2015). CAT is present in peroxisomes, while APX distributed in cytosol, chloroplast, peroxisome, and mitochondria. Both these enzymes are involved in detoxification of $\mathrm{H}_{2} \mathrm{O}_{2}$ (Khan et al. 2016b).

The protein contents increased with the Si application under salinity stress (Fig. 4). This was confirmed by other scientists in different crops, such as cucumber (Wang et al. 2015) and sorghum (Chen et al. 2016). Silicon application increases polyamine (PA) contents in sorghum and reduces the 1-aminocyclopropane-1-carboxylic acid (ACC) concentrations under salinity stress (Yin et al. 2016).

Gas-exchange parameters and $\mathrm{Chl}$ content: Salinity stress reduced the gas-exchange parameters in both 
genotypes except $g_{\text {s }}$ in EV 1089 (Table 2) resulting in reduced $\mathrm{CO}_{2}$ availability to the plant and restricting the $\mathrm{CO}_{2}$ fixation (Liu et al. 2015). There was detrimental effect of salinity on metabolic process of protein synthesis (Mateos-Naranjo et al. 2013), which led to photoinhibition and affected carboxylase activity of Rubisco (Antolín and Sánchez-Díaz 1993). Hence, in our experiment, the decrease in $P_{\mathrm{N}}$ and $g_{\mathrm{s}}$ (Table 2) can be attributed to modification of Rubisco enzyme activity. Silicon application increased $\mathrm{CO}_{2}$ assimilation and stomatal conductance in both genotypes under salinity stress (Table 3). Liang et al. (2005) also described the improvement in $\mathrm{CO}_{2}$ assimilation and stomatal conductance due to increased activity of Rubisco in barley crop under salinity stress.

$E$ was reduced with $\mathrm{Si}$ application under salinity stress (Table 2). This might be due to Si deposition beneath the cell walls in roots (Khan et al. 2016a) which hinders the translocation of salts and free water movement through xylem. Wang et al. (2015) also reported in cucumber that higher contents of $\mathrm{Si}$ might reduce $\mathrm{Na}^{+}$uptake and also cause restriction in bypass flow of water to maintain water status inside a plant body. The WUE was reduced in both maize genotypes due to applied salinity stress (Table 2); as plant growth faces initial osmotic adjustment (Liu et al. 2015). The WUE was improved with Si application under salinity stress in both genotypes. There might be two possible reasons for this increase: either the reduced transpiration is directly related to the plant water status (Wang et al. 2015) or the deposition of Si crystals under

\section{References}

Abbas T., Balal R.M., Shahid M.A. et al:: Silicon-induced alleviation of $\mathrm{NaCl}$ toxicity in okra (Abelmoschus esculentus) is associated with enhanced photosynthesis, osmoprotectants and antioxidant metabolism. - Acta. Physiol. Plant. 37: 1-15, 2015.

Acosta-Motos J.R., Diaz-Vivancos P., Álvarez S. et al.: Physiological and biochemical mechanisms of the ornamental Eugenia myrtifolia L. plants for coping with $\mathrm{NaCl}$ stress and recovery. - Planta 242: 829-846, 2015.

Allison L.E., Moodie C.D.: Carbonate. - In: Black C.A. (ed.): Methods Soil Analysis. Part 2: Chemical and Microbiological Properties. Pp. 1379-1396. Am. Soc. Agron., Madison 1965.

Ahmad M., Zahir Z.A., Khalid M. et al.: Efficacy of Rhizobium and Pseudomonas strains to improve physiology, ionic balance and quality of mung bean under salt-affected conditions on farmer's fields. - Plant Physiol. Bioch. 63: 170-176, 2013.

Antolín M.C., Sánchez-Díaz M.: Effects of temporary drought on photosynthesis of alfalfa plants. - J. Exp. Bot. 44: 1341-1349, 1993.

Ashraf M.A., Ashraf M., Ali Q.: Response of two genetically diverse wheat cultivars to salinity stress at different growth stages: leaf lipid peroxidation and phenolic contents. - Pak. J. Bot. 42: 559-565, 2010.

Bhutta W.M., Hanif M.: Genetic variability of salinity tolerance in spring wheat (Triticum aestivum L.). - Acta Agr. Scand. BS.P. 60: 256-261, 2010. the epidermal layer of leaves (Khan et al. 2016a) reducing the water loss through stomata or cuticle.

Chl $a$ and $b$ contents also decreased with applied salinity stress (Table 2). This might be due to the Chl degradation; it occurs when different proteolytic enzymes such as chlorophyllase started functioning under stress conditions (Sabater and Rodriquez 1978). The other reason is inefficient activity of photosynthetic apparatus (MateosNaranjo et al. 2013). Silicon application enhances the contents of both pigments under salinity stress conditions (Wang et al. 2015) as it was confirmed in this study (Table $2)$. The prominent increase in $\mathrm{Chl} b$ in both genotypes happened because of $\mathrm{Si}$ application under salinity stress.

Conclusion: The genotype Syngenta 8441 showed better adaptive mechanisms against salinity stress, therefore it must be preferred in salt-affected soils, while the genotype EV 1089 proved to be excellent in normal soils. In hydroponic study, both genotypes showed normal growth due to salt application at later growth stages. Differential accumulation patterns of $\mathrm{Na}^{+}$in tissues are one of the possible reasons for differences in salinity tolerance of both genotypes. The salt-tolerant genotype Syngenta 8441 restricts the $\mathrm{Na}^{+}$movement from old to young leaves thereby maintaining growth of young leaves. Silicon application improved growth of plants under salinity stress mainly because of changes in ion accumulation, improvement in photosynthetic rate, enzyme activities, and phenolic compounds.

Bayer W.F., Fridovich I.: Assaying for superoxide dismutase activity: some large consequences of minor changes in conditions. - Anal. Biochem. 161: 559-566, 1987.

Bradford M.M.: A rapid and sensitive method for the quantitation of microgram quantities of protein utilizing the principle of protein-dye binding. - Anal. Biochem. 72: 248-254, 1976.

Cakmak I., Marschner H.: Magnesium deficiency and high light intensity enhance activities of superoxide dismutase, ascorbate peroxidase, and glutathione reductase in bean leaves. - Plant Physiol. 98: 1222-1227, 1992

Chen A., Cao B., Qi L. et al.: Silicon-moderated K-deficiencyinduced leaf chlorosis by decreasing putrescine accumulation in sorghum. - Ann. Bot.-London 118: 305-315, 2016.

Cooke J., Leishman M.R.: Is plant ecology more siliceous than we realise? - Trends Plant Sci. 16: 61-68, 2011.

Gattullo C.E., Allegretta I., Medici L. et al.: Silicon dynamics in the rhizosphere: connections with iron mobilization. - J. Plant Nutr. Soil Sci. 179: 409-417. 2016.

Gee G.W., Bauder J.W.: Particle-size analysis. - In: Klute A. (ed.): Methods Soil Analysis. Part 1: Physical and Mineralogical Methods. Agron. Monogr. 9. Pp. 383-409. Soil Sci. Soc. Am., Madison 1986

Jones J.R.J., Case V.W.: Sampling, handling, and analysing plant tissue samples. - In: Westerman R.L. (ed.): Soil Testing and Plant Analysis, $3^{\text {rd }}$ ed. Pp. 389-428. Soil Sci. Soc. Am., Madison 1990. 
Kafi M., Rahimi Z.: Effect of salinity and silicon on root characteristics, growth, water status, proline content and ion accumulation of purslane (Portula caoleracea L.). - Soil Sci. Plant Nutr. 57: 341-347, 2011.

Khan W.U.D., Aziz T., Hussain I. et al:: Silicon: A beneficial nutrient for maize crop to enhance photochemical efficiency of photosystem II under salt stress. - Arch. Agron. Soil Sci. 63: 599-611, 2016a.

Khan W.U.D., Aziz T., Maqsood M.A. et al.: Silicon: A beneficial nutrient under salt stress, its uptake mechanism and mode of action. - In: Hakeem K.R., Akhtar J., Sabir M. (ed.): Soil Science: Agricultural and Environmental Prospective. Pp. 287-301. Springer, Cham 2016b.

Khan W.U.D., Aziz T., Warraich E.A. Khalid M.: Silicon application improves germination and vegetative growth in maize grown under salt stress. - Pak. J. Agr. Sci. 52: 937-944, 2015.

Khatoon T.K., Hussain A., Majeed K. et al.: Morphological variations in maize (Zea mays L.) under different levels of $\mathrm{NaCl}$ at germinating stage. - World Appl. Sci. J. 8: 1294 -1297, 2010.

Khayatnezhad M., Gholamin R., Jamaati-e-Somarin S.H., Zabihi-e-Mahmoodabad R.: Effects of peg stress on corn cultivars (Zea mays L.) at germination stage. - World Appl. Sci. J. 11: 504-506, 2010.

Liang Y.C., Chen Q., Liu Q. et al.: Exogenous silicon (Si) increases antioxidant enzyme activity and reduces lipid peroxidation in roots of salt-stressed barley (Hordeum vulgare L.). - J. Plant Physiol. 160: 1157-1164, 2003.

Liang Y.C., Zhang W.Q., Chen J., Ding R.: Effect of silicon on $\mathrm{H}^{+}$- ATPase and $\mathrm{H}^{+}$-PPase activity, fatty acid composition and fluidity of tonoplast vesicles from roots of salt stressed barley (Hordeum vulgare L.). - Environ. Exp. Bot. 53: 29-37, 2005.

Liu P., Yin L., Wang S. et al.: Enhanced root hydraulic conductance by aquaporin regulation accounts for silicon alleviated salt-induced osmotic stress in Sorghum bicolor L. Environ. Exp. Bot. 111: 42-51, 2015.

Mateos-Naranjo E., Andrades-Moreno L., Davy A.J.: Silicon alleviates deleterious effects of high salinity on the halophytic grass Spartina densiflora. - Plant Physiol. Bioch. 63: 115-121, 2013.

Morales SG., Trejo-Téllez LI., Merino F.C.G. et al.: Growth, photosynthetic activity, and potassium and sodium concentration in rice plants under salt stress. - Acta Sci.-Agron. 34: 317-324, 2012.
Munns R., Tester M.: Mechanisms of salinity tolerance. - Annu. Rev. Plant Biol. 59: 651-681, 2008.

Nakano Y., Asada K.: Hydrogen peroxide is scavenged by ascorbate-specific peroxidase in spinach chloroplasts. - Plant Cell Physiol. 22: 867-880, 1981.

Nelson D.W., Sommers L.E.: Total carbon, organic carbon and organic matter. - In: Black C.A. (ed.): Methods Soil Analysis. Part 2: Chemical and Microbiological Properties. Agronomia Mongr. 9. Pp. 570-571. Soil Sci. Soc. Am., Madison 1982.

Sabater B., Rodriquez M.I.: Control of chlorophyll degradation in detached leaves of barley and oat through effect of kinetin on chlorophyllase levels. - Physiol. Plantarum 43: 274-276, 1978.

Singleton V.L., Orthofer R., Lamuela-Raventós R.M.: Analysis of total phenols and other oxidation substrates and antioxidants by means of Folin-Ciocalteu reagent. - Methods Enzymol. 299: 152-178, 1999.

Steel R.G.D., Torrie J.H., Dickey D.A.: Principles and Procedures of Statistics. A Bio-Metrical Approach, $3^{\text {rd }}$ ed. Pp. 172-177. McGraw Hill Book Co., Inc., New York 1997.

Strain H.H., Svec W.A.: Extraction, separation, estimation and isolation of chlorophylls. - In: Vernon L.P., Seely G.R. (ed.): The Chlorophylls. Pp. 21-66. Academic Press, New York 1966.

Tahir M.A., Aziz T., Rahmatullah.: Silicon induced growth and yield enhancement in two wheat genotypes differing in salinity tolerance. - Commun. Soil Sci. Plan. 42: 395-407, 2011.

Tahir M.A., Aziz T., Farooq M., Sarwar G.: Silicon-induced changes in growth, ionic composition, water relations, chlorophyll contents and membrane permeability in two salt-stressed wheat genotypes. - Arch. Agron. Soil Sci. 58: 247-256, 2012.

Tuna A.L., Kaya C., Higgs D. et al.: Silicon improves salinity tolerance in wheat plants. - Environ. Exp. Bot. 62: 10-16, 2008.

Waskiewicz A., Muzolf-Panek M., Goliński P.: Phenolic content changes in plants under salt stress. - In: Ahmed P., Azooz M.M., Parsad M.N.V. (ed.): Ecophysiology and Responses of Plants under Salt Stress. Pp. 283-314. Springer, New York Heidelberg - Dordrecht - London 2013.

Wang S., Liu P., Chen D. et al.: Silicon enhanced salt tolerance by improving the root water uptake and decreasing the ion toxicity in cucumber. - Front. Plant Sci. 6: 759, 2015.

Yin L., Wang S., Tanaka K. et al.: Silicon-mediated changes in polyamines participates in silicon-induced salt tolerance in Sorghum bicolor L. - Plant Cell Environ. 39: 245-258, 2016. 